\title{
THE ROLE OF MOSQUE IN EDUCATION OF PRESCHOOL CHILDREN (Study of some educational books for preschool children and mosque)
}

\author{
R.A.Anggraeni Notosrijoedono \\ Department of Social Welfare Science \\ Faculty of Social and Political Science - University of Indonesia
}

\section{Abstract}

The existence of mosque is inseparable from the aspect of community education. Mosque can give various contributions, one of them in educating preschool children surrounding the mosque. Mosque comprises of various facilities of room and veranda can be used for various kinds of programs, one of them is education program for preschiool students. Education for preschool children initially is conducted in one of rooms or veranda of mosque, if it is organized kindly can develop and has its own building.

One of the activities conducted for preschool children is Playing Group. The initial arrangement of Playing Group by some amount of students didn't need wide land, however more students follow the Playing Group it needs wide room and land. On the ground education for preschool children needs great number of games indoor and outdoor. Through the playing function, it can influence children's development; e.g. physical development, i.e. hard and soft motoric competence, by playing, children's body will be more flexible. By conducting 49 kinds of funcationl playing in every Playing Group existing in mosque, hopeful the development in childhood of every child will be passed kindly.

The total of mosque in Indonesia is 193.893 mosques by total of preschool children (0-6 years old) totalled 28.912 .400 children, thus if every mosque is commanded to conduct Preschool Children Education hopeful twenty years later Indonesia will gain human resources who conduct their religion kindly, have good moral, smart and polite. Thus it needs cooperation between the policy maker of education for preschool children in Ministeriate of Religion and Ministeriate of National Education.

Keywords: Mosque, Preschool Students Education, Playing Group, children's development.

Keberadaan masjid tidak dapat dilepaskan dari aspek pendidikan umat. Masjid dapat memberikan berbagai sumbangan, salah șatunyà dalam mencerdaskan anak usia dini disekitar masjid. Masjid terdiriddari beberapa fasilitas ruangan dan serambi yang dapat digunakan untuk berbagai macam program, salah satunya adalah program pendidikan anak usia dini. Pendidikan anak usia dini yang awalnya diadakan di salah satu ruangan atau serambi masjid, jika dilola dengan baik dapat berkembang dan mempunyaigedung sendiri.

Salah satu kegiatan yaing dilakukan untuk anak usia dini adalah Kelompok Bermain. Awal berdirinya Kelompok Bermain dengan jumlah siswa sedikit tidakmemerlukan tanah yang luas; tetapi semakin banyak siswa yang mengikuti Kelompok Bermain diperlukan ruangan dan tanah yang luas. Karèna pendidikan anak usia dini memerlukan banyak permainan di dalam dan di luar ruangan. Melalui fungsi bermain, dapat mempengaruhi pertumbuhan anak, seperti pertumbuhan fisik yaitu keterampilan motorik kasar dan halus, dengan bermain tubuh anak akan menjadi lebih fleksibel. Dengan menyelenggarakan 49 jenis bermain fungsional pada setiap Kelompok Bermain yang berada di masjid, diharapkan perkembangan masa kanak-kanak setiap anäk akan dilewati dengan baik.

Jumlah masjid di Indonesia yaitu 193.893 buah dengan jumlah anak usia dini (0 - 6 tahun) sejumlah 28.912.400 anak, maka jika setiap masjid dihimbau untuk menyelenggarakan Pendidikan Anak Usia Dini 
diharapkan dua puluh tahun mendatang Indonesia akan mendapatkan sumber daya manusia yang menjalankan agama dengan baik, bermoral, cerdas dan santun. Dengan demikian perlu kerjasama antara pembuat kebijakan pendidikan untuk anak usia dini di Kementrian Agama dan Kementrian Pendidikan Nasional).

Kata Kunci: Masjid, Pendidikan Anak Usia Dini, Kelompok Bermain, pertumbuhan anak.

\section{INTRODUCTION}

een from the history, the emergence and development of mosque in Indonesia along with the emergence and development of Islam in Indonesia brought by merchant/trader from Gujarat. Mosque is a basic of development and Islamic speech to whole Java Island and other areas in Indonesia. In the book Pedoman Pembinaan Kemasjidan, it mentions that mosque is a building for a place to Moslem used for doing shalat rawatib (five times a day) and Jum'at (p:2,2008). In phase of Islam spreading at that time, mosque had functioned not only as a place for merely praying, instead it also has function as educational institution and Islamic Speech in book Mosque Empowerment (though aspects of Idarah, Imarah and Ri'ayah) mentions the function of mosque includes as follow:

1. Construction of organization or Idarah. Its task includes the organizational, institutional, personal, administrative, financial issues, et cetera.

2. The construction of mosque prosperity or Imarah. Its task includes the construction, praying, construction of formal education (either religious education or general education), beyond school/nonformal education (e.g.:

- taklim committee, Al Quran Educational Ground, construction of mosque teenagers and library). The celebration of National Holiday and construction in social field.

3. Ri'ayah construction is the construction of mosque in building physical field, media and prerequisite as well as : other mosque equipments (h:1.2007).

In development of Imarah field, it is inseparable from the meaning of word Imarah according to the terminology is an effort to make prosperity for mosque as praying site, construction of community and increase of jama'ah prosperity. Mosque is Allah's house should be maintained for its holy and highness. Making prosperity for mosque is development process of mosque programs. Making prosperity for mosque has objective to increase the activity and performance of mosque and multifunctional function of mosque. Thus every moslem should participate in making prosperity for mosque. In order to increase mosque prosperity, the programs should be conducted appropriate to the function of mosque itself, in addition of mentioned above, as follow: function of praying site, site of social (nonformal) education, center of Islamic speech, site to increase jama'ah prosperity, mosque teenagers, social health, library, celebration of Islamic and national holiday as well as site for consultating on religion for society.

Education can be conducted in mosque more to nonformal education. Nonformal education in mosque is more emphasized to religious aspect. Nonformal education can be conducted in mosque are: Taklim Committee, Playing Group, Al Qur'an Educational Ground/AI Qur'an Kindergarten School, religious courses. Elimination of - Illiteral (AI Qur'an and Latin) as well as Equational Education (Achieving Package A, B and C).

Taklim Committee is nonformal educational institution and one of the traits of religious nonformal education. Learning or studying process in Taklim Committee is followed by relatively many educative members and often mentioned as Jama'ah. Jama'ah or education members of Taklim Committee includes age of children, teenagers, adults and olders. It is appropriate to principle of Life Long Education and Education for All.

In addition of Taklim Committee, other non-formal education can be conducted in mosque are Playing Group, AI Qur'an Educational Ground/AI Qur'an Kindergarten Ground (TPQ/TKQ). TPQ is non-formal educational 
institution which specifying in Al Qur'an education and religious study for preschool children ( $0-6$ years old) and Elementary School Age Children and Junior High School (7 to 14 years old). This education institution grows and develops as result of creation and innovation of society and Moslem Social Organization.

Nowadays government of Indonesia very concerns to Education of Preschool Children/PAUD, it seems from the great number of PAUD schools in thorough areas in subdistrict level. The data author gained at Tuesday, March $15^{\text {th }}$ of 2011 from Directorate General of Non-formal and Informal Preschool Children Education/Ditjen PAUDNI - Ministry of National Education of Republic Indonesia/Kemdiknas (the change of Ditjen name has been initiated in January 2011). Data of number of Random Participation/APK in 2010/2011 totaled preschool children from 33 provinces spreading in 13.000 islands in Indonesia are 28.912 .400 children by range age of $0-6$ years. The biggest amount for preschool children existing in West Java Province totaled 5.155.528 children of which spreads 25 regencies. In addition, East Java Province is 4.170 .302 children spreads in 38 regencies. Followed by Central Java Province is 3.144.764 children spreads in 35 regencies. Then North Sumatra province is totaled 1.632.116 children in 25 regencies. Banten is totaled 1.388 .798 children, South Celebes is 1.047 .710 children and Jakarta Capital City totaled 1.007 .596 children spread in 6 regencies. PAUD consists of Non-Formal PAUD and Formal PAUD. Non-formal PAUD comprises of Children Caring Ground/TPA, Playing Group/KB and Unit of Some kind PAUD/SPS. Meanwhile FormalPAUD comprises of Kindergarten/TK or RaudhatulAthfal/RA.

By considering above PAUD data, thus on national level it has been governmental policy concerning on preschool children education and it had been written in document of Preface of Constitution of Republic Indonesia of 1945/ UUD 1945 stating "... therefore, to create a Unity of Indonesia State that has community sovereignty, educate state life, and participates in conducting world order based on independence, long lasting peace, and social fair, ...". Thus learning process is very necessary since preschool age, in order Indonesia gain human resources that have moral, high knowledge, highly esteem values of affection and spirit of cooperation.

It also exists in Amendment of Constitution of 1945 article $28 \mathrm{C}$ paragraph 2 that every child has right to develop himself through the fulfillment of their basic needs, has right to gain education and receive the function of science and technology, art and culture to increase his life quality and for the prosperity of human. Thus if the basic needs of children has been fulfilled, e.g. foods, good nutrients, education, and knowledge and technology, art and culture it will be the capital for children if they have been adult and can change their life to be better and prosperous.

Such was the case in 1990 the government had showed preschool children education by the establishment of Governmental Regulation Number 27 of 1990 on preschool education, wherein in article 1 has been explained that preschool education is education to help development and growth of both physic and psychic of educated children beyond familial environment before they pass into elementary education conducted in line of school education and education line beyond school.

The government through Ministry of National Education of Republic Indonesia established Decision Number 05.1/02/2001 on the Establishment of Directorate of Preschool Children Age Education/PAUD as effort of government to improve and flatten preschool children education in Indonesia to be more concentrated. Seems from direction of policy on PAUD in Indonesia, it has:

Mission: The manifestation of preschool children who are smart, health, happy, and have fine moral, and has readiness either physical or mental in entering next level of education.

Vision: 1. Strive the flatening of service, quality increase, and efficiency in conduction of preschool educatoin; 2. Strive the increasing of consideration and competence of society in providing preschool education service; 3 . Prepare the children at earlier in order in future they have readiness to enter the next level of education. 
In addition, the government gives concern to children by the existénce of Act Number 23 of 2002 on Children Protection of 2002 article 4 stating: Every child has rights to be alive, grow, develop, and participate appropriately to dignity and esteem of mankind, and gain protection from violence and discrimination. Similarly in article 9 is st ated (1) every child has right to gain education and teaching in order to develop his personality and level of smartness appropriately to his skill and competence. (2) In addition of children's right as mentioned in article (1), in particularly for children with disoders also have right to gain extraordinary education, meanwhile the children who has speciality also gain special education. Thus, the government has considered the existing potential in every child by his superiority and lack will success if every child is considered from unique pespective.

The concern of Government to children also seems clearly by existence of Act of Republic Indonesia Number 20 of 2003 on System of National Education article 1, paragraph (14) stating every preschool education is a constructive effort pursued to the children since they were born to six years conducted through the providing of educational stimulus to help the growth and development of either physic and psychic of children, in order they have readiness in entering next level education. Then in article 28 stating that every preschool children education can be conducted through formal, non-formal, and informal educational line.

Along with the development of preschool children education, thus in September $17^{\text {th }}$ of 2009 , Government stated Regulation of Minister of National Education of Republic Indonesia Number 58 of 2009 on Standard of: Preschool Children Education established by Ministry of National Education -Directorate General Management of Elementary and Middle Education-Directorate of Construction of Kindergarten and Elementary. In article 1 paragraph 1 states Standard of preschool education includes formal and non-formal education comprises of: a. Standard of development achievement level; $b$. Standard of educator and educational staff; $c$. Standard of content, process, and evaluation; d. Standard of medium and prerequisite, management, and funding.

By the great attention of government in preschool children education, hopeful in future Indonesia will gain human resources who are smart appropriately to their skill and interest. Moreover it is supported by role of mosque in conducting preschool education.

The existence of policy in national level on the importance of PAUD, hopeful the schools that conduct PAUD, e.g. Playing Group with its playing program can also develop the social competence of children through social contact in a game, the children learn to be cooperative, wait their turn and follow the playing rule. If it is conducted since preschool it will influence to their life in future, by reason children are one of parts in community.

The role of mosque in preschool education needs to be considered by people and governmental institutions operating in mosque as well as they who are concern to the preschool education. By reason through initial preschool education, a child can develop kindly appropriate to his age. In the case government has considered the children since initial age by establishing the policies which profit to the development of children, thus it needs the cooperation from Ministry of Religion and Ministry of National Education by various kinds of profession to support the continuity of preschool education conducted by mosque. The initial establishment in mosque by Playing Group has Islamic nuance and the next step can enter into Kindergarten and then Elementary School to University. Thus if every mosque can create continual educational program, it will be better human resources of Indonesia in the next twenty years.

Thus the policy in Ministerial level can be implemented in the lowest level, i.e. through activity in mosque based on the most primary necessity of society surrounding the mosque.

\section{METHOD}

The approach of this study was qualitative approach and has descriptive characteristic. Meanwhile those who became informan in this study was: 
1. Organisator of mosque, behalfas mosque which conducting preschool education.

2. Educator, behalf as educating teachers for preschool children.

3. Supervisor of Preschool Children, to gain comprehension on the importance of playing for development of children in initial age.

4. Guard of Playing Group, as leader who exists in school everyday and comprehend that the role of playing has very big influence to children development.

5. Head of Association of Indonesian Educator and Educational Staff of Preschool Children/HIMPAUDI -Sleman Regency Branch-Yogyakarta Special Region, behalf as leader of HIMPAUDI in central level.

The scope of this study is limited to the preschool children who are $2-4$ years old and follow the activity in Playing Group which is one of the activity program of mosque in education field.

\section{DISCUSSION}

The activity in mosque can be conducted continually, one of them is through Preschool Children Education program. Education will always develops by reason of exist some steps, e.g.: initially it makes program of Playing Group, and then Kindergarten School, and so on. Initially the activity for preschool children is conducted in one of the room or veranda of mosque, mushall and small mosque. However in next development is is conducted in other sites, instead it can build its own building, by reason it has more students. As non-formal educational institution that stand alone, the development of Playing Group is more self-reliance and can have its own building beyond the mosque.

Management of Playing Group is insèparable from management of other education. The elements of management existing in Playing Group are:

1. Curriculum directing to Regulation of Minister of National Education of Republic Indonesia Number 58 of 2009 on Standard of Preschool Education established by Ministry of National Education-Directorate General of Management of Elementary and Middle Education- Directorate of Construction of Kindergarten and i Elementary School.

2. Educators should have sufficient knowledge in Al Qur'an and religion field.

3. Students.

Based on data from the book Pedoman Pembinaan Kemasjidan of 2005, in Indonesia there are 193.893 mosques $=30.084 \%$, langgar $=388.375$ langgars $=60.259 \%$ and mushalla totalled 62.234 mushallas $=9.656 \%$. Totalal of entire is 644.502 . Thus if mosque, langgar and mushalla locates in. Village/Subdistrict in 33 Province in Indonesia can be outsourced by Moslem continually and goes on, thus it can increase the quality of life includes health, education, cooperative, cooperation and social praying.

The role of mosque in development of preschool children needs to be considered, moroever Indonesian people are mostly Moslem and there are 1.93 .893 mosques spreading all over in 33 province in Indonesia. It can be imagined in the next twenty years, Indonesia gain a good-quality in fields of religion, art, music, social, and science.

Mosque includes one forms of social service to society having Islam religion. The meaning of social service according to Brenda Dubois and Karl Krogsrud Miley (1992) is social service as a support for increasing the 'social-function or to fulfil individual needs, inter-individual or institutional. In addition, in Ensiklopedia Pekerjaan Sosial Indonesia (2004: p. 98), state those which is meantioned as social service is social service can be seen as "providing general facilities aimed to increase individual and group prosperity and help indeeds people". Thus social service according to Alfred J. Kahn (1973) includes service of health; education and public settlement or 
programs such as children and familial prosperity, service for olders and various counselings and assistance in schools, hospitals, and other same kinds facilities. Moreover Alfred J. Kahn wrote that the task of social service includes: 1) To strengthen and repair the functionality of family and individual appropriately to the had roles; 2) Create new institution in order to socialization, development and assitance (formerly is the role of main family however it is no more); 3) Develop institutional shapes in order to create new activites considered as important to individuals, families and groups in complex urban society.

Preschool children having age range $0-6$ years and mentioned as golden age and have extraordinary change if observed from the newborn and then grown into a children. Fetus receives supply of oxigen, food extract, blood circulation, process of secresion as well as temperature regulation still depends to his mother. While born, newborn should conduct various matter by his effort and post-natal demands the newborn to be self-reliance. Then, it seems the emergence of reflexes which are the basic of sensitibility to the stimulus, the emergence of chat which will develop into competence to communicate and the children has developed their physic thus it has been create proportional body, able to walk, jump, run, able to hold brush and pencil nicely, able to communicate with other person using verbal language, able to comprehend emotion felt by other person based on showed body language.

At golden age, children needs appropriate stimulus to achieve the perfect maturity, because at this period it is also mentioned as critical period by reason it very influences the success in the next period. If at this critical period they did not gain appropriate stimulus in the shape of training or learning process, thus approximated the children will have disorders during their next development period.

According to Freud, this preschool should be given strong foundation in order prevent the characteristic or emotional disorder. Freud also states that disorders had in adult can be reversed back by considering the life during their childhood. For example: the agresive person verbally, often to be angry and slander, in fact at initial age did not have satisfaction toward their needs. Such was Erikson states that children who did not have any disoder and have affection and did not gain any satisfaction towards their needs will have failure to develop belief to other person. Meanwhile Piaget states that the initial years of human development is an exact period to introduce various simple concepts as basic for developing the more complex reasoning method in the next development steps.

Development of children at $0-3$ years old according to a survey conducted in USA, the pattern of newborn physic since born up to the age of 12 months/1 year follows certain pattern in particularly those which relates to body weight and height. Such was the development of newborn since they were born up to the age 3 years can be seen from the age, motoric development, adaptive behavior, linguistic competence and social and personal behavior, for example: the newborn in the age of 4 weeks, his motoric development likes the head flexibility, strong neck, holding fingers and adaptive behavior by staring around by the narrow range by reason the visual competence is still limited. Meanwhile the linguistic competence by the emergence of small voice came from throat and become attracted to the voice of bell, as well as social-personal behavior by observing faces.

At the age of 3 years old, seems the better motoric development by becoming able to stand up on a leg, building menara from 10 cubes and linguistic competence has been better by the total of vocabulary achieves 1.000 words and $80 \%$ of phrase has been easy. Such was the cognitive competence of children also increase, herein the children conduct problem solving, utter ideas, et cetera. It started to conduct during the children were still newborn, wherein the children founded something from their action which caused a reaction. For example: pressing toy and the toy results any voice.

The meaning of Playing Group is one of shapes of preschool education in non-formal educational line that provide educational service to the children at the age of $2-6$ years old, to help development and growth of 
children, in order in future they are ready to enter the next level education. Playing Group prioritizes playing activity while studying, thus the principles of education in Playing Group are:

1. Every child is unique, they grow and develop from difference competence, necessity, willingness, experience and familial background.

2. Children at the age of 2-6 years old is a child who interests in playing. For them playing is the way they learn. Thus the playing activity should be able to facilite the variety of studying method in situation of happy, voluntary and affection by make function the surrounding environmental condition.

3. The educators who have taks in playing activity is educators who has willingess and competence in educating, comprehending children, full of affection and tender, as well as prepared to play with children.

Playing Group at this time is a necessity for the couple of young parent who mutually work, or mutually unemploy. By reason of there has been standard of medium and prerequisite to create Playing Group from government.

In activities in Playing Group there are various kind of functional play, such as: Sandra J. Stone in her book Playing; A Kid's Curriculum explains that (1993: p.15-65) functional playing is a game played by children for the first time, thus the children gain their first experience. The children is free to express appropriate to their emotion. For example randomly draw on the papper with color pencil. Functional playing develops children's sensory-motoric. Piaget assumes functional playing by practice of playing. Functional playing is also said as manipulative play where in children develop their motoric with or without any objects. In additin functional playing is mentioned as explository playing, wherein children exploring their environment by interaction. Herewith, given 49 samples from functional playing, i.e.:

1. Jews threads. It attracts the children to enter the color objects into the thread to create a necklace - small motoric development. Playing advantage: the children can think on mobility and take a decision, obedient to rule started with the small sized object to bigger one and so on. Fix with the color, and can differentiate the color with the shape of object and attract the children to count the amount of object.

2. Bouncing the ball. Learning to bounce the ball onto the floor - motoric development, coordination of eyes, development of perception and concept. The advantage of playing: attract the children to concentrate, likes the children as the basketball player, the children can enter the ball into the basket, and can differentiate the color and shàpe of the ball.

3. Cutting papers. Providing newspaper and then ask the children to cut the paper appropriate to the appropriate size. The advantage of playing: the children can circle the paper they cut and then give color respectively and the children learn about the size, shape, and colorby cutting the paper.

4. Guess the box. Providing box with various objects inside, and then the other peers guess what the contents by touching the object. The advantage of playing: the children develop motoric competence by touching, the children use language and solving problem and learn to communicate with peers, and the children count the item and children and categorize the item.

5. Imitating animal voice. Imitating animal voice appropriate to the existing picture on blackboard. The advantage of playing: the children can draw their favorite animal, the children take the role like become an

2 animal by imitating the animal voice, and children interact with peer, sing, and linguistic development.

6. : Break the egg. Ask the children to break egg and fix the color. The advantage of playing: the children solve problem by trying to break the egg, the children take the role like preparing breakfast, and the children discuss with peers concerning on the classification of color. 
7. Frog jump. Provide some box and then ask the children to jump over it on by one exactly. The advantage of playing: the children can use the simple box into playing media, the children ask something each time they success to jump into the box, the children will be aware refrain the failure to enter into the box during jumping, and the children solve the problem, feel the size in the box.

8. Sweep ball away. Provide place and colorful balls disarranged on the floor. Ask the children to clean and collect appropriately to the color. The advantage of playing: the children can color the balls, select balls appropriately to the calculation and color, and children can count the balls.

9. Pass through the barrier. Cut some paper or other object as a barrier and then pass through the barrier without touching the object. The advantage of playing: the children can create barrier; children can create hat from newspaper; and children can create circle, box, or square by newspaper.

10. Playing with natural object. Ask the children to play by classifying the object with the similar shape. The $\therefore$ advantage of playing: the children acknowledge many shapes, and the children communicate with their peers, the children can count the total of item.

11. Create line. The children create line using used roll-on and then the roll-on ball is took off and entered into the bottle and then played. The advantage of playing: the children learn to.draw shape, the children can enter the object into bottle, and the children learn some colors.

12. Throw marble. Ask the children to prepare marbles and throw them by using pipe. The advantage of playing: children can create marble from paper, learn to arrange the marble, able to differentiate size, colọ, and shape and the children learn to throw èxactly.

13. Walk on the board. Provide a board by sufficient width, and let the children one by one pass through it during starching away their arms. The advantage of playing: the children try the balance by standing on a board, and the children learn to wait their turn and learn to walk kindly.

14. Taking the object inside the box. The children areasked to select mentioned objects by looking for it inside the box fulfilled with toys. Advantage of playing: the children feel curious like looking for any treasure, the children can identify and learn to classify.

15. Select cotton. The children take the disarray cotton on the floor and then take it into a basket. Advantage of playing: the children learn to clear up, children take over the cotton and playing quiz, and children can count the cotton, and tell where the cotton come from.

16. Playing sand. Provide box with sand and liter with spade. Advantage of playing: children can explore some objects in the box, for example learn to dig, solve problem, build mount, build street and play cars inside.

17. Climb. Provide ladder from cube to climb by children. Advantage of playing: children learn to count the cube, children learn to climb on the ladder one by one and play who can guess thus can climb; it makes students learn to be competitive.

18. Playing cooking. Provide some foodstuff and cooking ware. Advantage of playing: children learn to cook and use the ware.

19. Experiment with water. Provide different shape of box and water. Advantage of playing: children can comprehend the trait of water likes poses all space, children can play ship and children communicate with their peers:

20. Washing stone. Provide stone, cloth, and box with water. Teach the children to wash the stone and dry it. Advantage of playing: children can feel the weight of stone, learn to wash and learn to color the stone. 
21. Play magnet. Provide nail or other metal and a magnet. Arrange nail or arranged metal and pull with magnet. Advantage of playing: children know the function of magnet and metal.

22. Wash the dish. Provide dish and liter with water. Ask the children to wash it. Advantage of playing: children learn to soap and dry using cloth, children can feel the role of mother and learn to aware in maintain the dish not to break.

23. Fix the shape of object. Provide box with appropriate form and object. Ask the children to fix appropriate to the shape.Advantage of playing: children can know various kinds of object, children can classify and children can create by themselves the shape by using newspaper.

24. Playing clothes pincer. Provide box and pincers, ask the children to pinch in all over parts of box. Advantage of playing: children learn to create pyramid with pincer and create digit or font.

25. Varying the color. Provide paper and painting media likes ketchup, sausage or mayonnaise. Advantage of playing: children can use the tool and create color appropriate to their expression and they learn color.

26: Fix the object with cover. Provide some objects with its cover. Ask the children to fix the object with the cover. Advantage of playing: children can learn some shapes of object, discuss with the friend in team and problem solving:

27. Push the box, provide box and rope. Ask the children to push the box of which every step is given the object into the box. Advantage of playing: children feel the burden every walking by reason object entered and the children learn not to surrender.

28. Playing to kiss the knee. Provide box and some objects having sharp smell. Advantage of playing: children can acknowledge object from its smell and children can differentiate the taste from the smell, for example sweet or hot smell.

29.: Playing by hearing sound. Provide box and object resulting a sound. Ask children to guess the object from the sound. Advantage of playing: children acknowledge the sound, and children can learn to differentiate sound, for example soft, hard, rhythmic sound, et cetera.

30. Playing key. Ask the children to open the log by using appropriate key. Advantage of playing: children can find log and appropriate key and solve the problem.

31. Playing sponge with water. Provide sponge with water. Wet the media and then clean with sponge. Advantage of playing: children know the function of sponge, learn to take a role as servant, know the difference of sponge size before and after the use and squeeze the sponge.

32. Painting the wall. Provide paints and brush. Ask the children to express by painting the wall. Advantage of playing: children learn to express, children know the equipments to paint the wall and learn about colors:

33. Push the retsluiting. Provide retsluiting and ask children to learn to open and close. Advantage of playing: train children are motoric, draw on the retsluiting cloth, and differentiate the size, shape; and color.

34. Playing the box. Ask the children to fix the object with the shape and then compile it. Advantage of playing: children learn to arrange the object, classify the shape, learns the size and color.

35. Playing sandpaper and wood board. Ask the children to fix the pattern of sandpaper with the wood board. Advantage of playing: know the pattern, learn to decide and by cube create buildings.

36. Filtering sand. Provide sandbox and filter. Ask children to filter the sand. Advantage of playing: playing with various colors of sand and see the difference after the sand had been filtered. 
37: Shoes and shoes.rope. Ask children to bundle the shoes rope. Advantage of playing: children can bundle the shoes rope by themselves, fix the color of rope with the color of shoes and train the diligence by using eyes.

38. Fix the shape of nuts. Provide nuts in various kinds of shapes. Advantage of playing: learn to classify nuts according to the shape and create nuts circle on the floor.

39. Move forwards by using box. Provide box at equal size with body and ask children to enter into the box and then slowly move forward. Advantage of playing: children learn to be competitive who is faster with their peers. and by using box introduce the children to up, down, bottom and top.

40. Fix the tiles color. Provide various color tiles and ask the children to classify the tiles appropriate with their colors. Advantage of playing: acknowledge the shape of tile and color, learn to classify and learn to count.

41. Draw on the sand. Provide sand in small box and rib. Ask the children to draw on the sand. Advantage of playing: children learn to draw, children can jump onto the sand and count the total of footprints of their jump (it is one of the way they draw) by footprints.

42. Wrap the gift. Provide box and plaster. Ask the children to paste the box with the help of plaster. Advantage of playing: can create object, children learn to create gift and learn about the shape.

43. Playing by blow the soap bubble. Ask the children to blow the soap bubble to the air. Advantage of playing: children can know the color of soap; seeing the traits of soap i.e. producing transparent bubbles.

44. Spoons disarrayed cotton. Ask the children to clear up the cotton by spooning it up and enter it into the box. Advantage of playing: learn about the shape of cotton and the origin, and learn to clear up.

45. Arrange cube. Ask the children to arrange the cube upward and keep it not to fall. Advantage of playing: stimulate the children's reasoning method by taking the big box to bottom and the smallest to the top to maintain the box to refrain falling.

46. Planting. Ask the children to plant plants on the soil, use spade and water for watering. Advantage of playing: the children know about the way of planting, children learn to take care of the plants and learn to take responsibility.

47. Play running around. Ask the children to run and catch. Advantage of playing: children learn to be competitive, train the children's physic, learn to count and imitate the run of animal.

48. Sounding music. Ask the children to use music by simple equipment and learn the music appropriate to the rhythm. Advantage of playing: the children can use the simple equipments as music tools and children learn to harmonize the sound of music tools.

49. Fix the shape according to order. Ask the children to take the object which is appropriate and orderly. For example square with square, small is entered into the bigger one and so on. Advantage of playing: differentiate the shape and know the size of small and big shape.

The attractive playing tools will motivate, challenge and entertain the children, thus the care given by adults in playing activity of children will enrich the experience, either for the children or adult. If every Piaying Group in mosque can conduct 49 activities of functional playing, hopeful the childhood will be passed through with positive things for the development of a child.

Thus, Playing Group in mosque environment is an actitivy which has practical value, it means playing is a media to increase certain capability and competence of children and a bridge for children to learn formally and non-formally. Golden age is the beginning of process of development of intelligence in preschool children, as well as the necessity of growth and development of children includes nutrients, health and education is a unity which 
needs to consider since preschool. The result of current research shows $50 \%$ of development of chlidren's intelligence at the age of $0-4$ years, thus if the children is lack of nutrients, lack of care on their health, education and social relation, thus the development of their intelligence will not run kindly. The primary point is the children learn many things through playing.

Thụs, Playing Group in mosque if it is organized appropriately is an activty of which has practical value. It means playing is used as media to increase the certain capability and competence in children and as a bridge for the children from learning formally and informally will make the children to be discipline, life higienically, tidy, precise, trusthworthily, charitable, grateful, sincere if accepting something, smart, not easy to, express emotion and has good moral. Thus the lesson of Islam religion gained from preschool can be implemented at adultage.

\section{Conclusion}

There are 193.893 mosques in Indonesia by total of preschool children from 33 provinces spreading all over in 13.000 islands in Indonesia. There are 28.912 .400 children by age of $0-6$ years. By the plenty amounts of total mosques and preschool children, hopeful there will be cooperation between Ministry of Religion and Ministry of National Education in preschool"education field. By reason the next twenty years the children who nowadays has preschool age will be the human resources of Indonesia who has quality since preschool has been included Playing Group existing in Mosque. The children under age of 6 years is better to participate non-formal education, likes Playing Group. By reason of influence of playing towards the development of preschool children's intelligence is very great. It is possibly the adult has not knew the psychic development of children will think why by only playing and singing of which included in teaching material in Playing Group will influence the preschool children's intelligence. Thus, it seems the function of playing can be a hint to find, think, idea, bridge of social relation and the direction of emotional balance. Through playing, a child can develop the competence of physical development through development of hard motoric, e.g. through playing of lifting, piling, pushing, pulling, and hiking. It also develops soft motoric, e.g. cutting following a drawing, play puppets, card, arrange cubes into a pile, helps the development of coordination between hand and eye. It also influences intellectual development, e.g. observing the relation between the size and weight, calculate, pasting, classifying, associating with peers, and comprehending symbols. Social development in preschool children can also develops; i.e. by having mutual responsibility, coordinate with group, cooperate, connect friendship is an effort to build the self-reliance and individual responsibility.

Such was the cognitive development or thinking competence more increases while the size, capacity and special function of children's brain in the step of reasoning growth and problem solving also increase rapidly. They will be able to think more logically, look for way to explain their tasks and remember many things in more details for the longer period. Meanwhile in linguistic competence or symbolic reasoning in children, it develops rapidly in this period. While the cognitive competence grows, they started to think symbolically through the use of language. They will use words to change drawing and body motion, as well as started to comprehend the meaning of various concepts. They use words to convey their intention, sharing emotion, and social interaction. Vocabulary at'the age of 6 years has had vocabulary of at least 10.000 words, comprehends the basic rule of grammar, and started to have addition of vocabulary as much 6 to 10 new words everyday.

At the psychological growth children concerning on the self comprehension during the children grows physically and cognitively, they will also start to realize their own existence. They will acknowledge the parts of their body, show off their toys, simply draw themselves and their family, and mention their name and age. Such was the emotional expression or competence for sharing emotion psychologically in children has passed through the period of "react by crying" and can be able to convey their emotion, willingness and intention by more appropriately. Meanwhile the social skill or competence to social interact in children will increase while they started to relates with 
more persons in house and in surrounding environment. Moreover the mosque with its Playing Group can conduct 49 kinds of functional playing for preschool children.

\section{BIBLIOGRAPHY BOOKS :}

Berk, Laura E. (2006). Child Development. Seventh Edition. Boston, New York, San. Francisco, Mexico City, Montreal, Toronto, London; Madrid, Munich, Paris, Hong Kong, Singapore, Tokyo, Capetown, Sydney: Pearson International Edition.

Brow; Catherine Caldwell. (1985). Play Interactions The Role of Toys and Parental Involvement. New York: Baby Product Company.

Direktorat Pendidikan Anak Usia Dini - Direktorat Jenderal Pendidikan Nonformal dan Informal - Kementerian Pendidikan Nasional. (2010): Pedoman Teknis Penyelenggaraan Kelompok Bermain. Jakarta: Direktorat Pendidikan Anak Usia Dini - Direktorat Jenderal Pendidikan Nonformal dan Informal Kementerian Pendidikan Nasional.

Direktorat Pendidik dan Tenaga Kependidikan Pendidikan Nonformal. (2007). Pedoman Penerapan Pendekatan "Beyond Centers and Circle Time (BCCT) "(Pendekatan Sentra dan Saat Lingkaran) Dalam Pendidikan Anak Usia Dini. Jakarta: Direktorat Pendidik dan Tenaga Kependidikan Pendidikan Nonformal.

Direktorat Urusan Agama Islam dan Pembinaan Syariah. (2007). Pedoman Pemberdayaan Masjid (Melaluiaspek Idarah, Imarah dan ri'ayah). Jakarta: Direktorat Jenderal Bimbingan Masyarakat Islam - Departemen Agama R.I.

Direktorat Urusan Agama Islam dan Pembinaan Syariah. (2008). Pedoman Pembinaan Kemasjidan. Jakarta: . DepartemenAgama R.I.

Kantor. Wilayah Departemen Agama Provinsi Daerah Istimewa Yogyakarta. (2007). Masjid Bersejarah Provinsi Daerah Istimewa Yogyakarta. Yogyakarta: Sholahuddin Offset.

Mallon, Gerald P. and PEG McCartt Hess. (2005). Child Welfare for The Twenty-First Century: A Handbook of Practices, Policies and Programs. New York: Columbia University Press.

Rudolph, Marguerita, Colhen, Dorothy H.(1984). Kindergarden and Early Schooling. New Jersey: Prentice- Hall, Inc.

Scarlett W. George, Naudeau, Sophie, Salonius, Dorothy-Pasternak, Ponte, Iris. (2005). Children's Play. United States of America: Sage Publications.

\section{LEGISLATION :}

Undang-undang Republik Indonesia. No: 2 Tahun 1989 Tentang Sistem Pendidikan Nasional dan Peraturan Pelakksanaannya. Jakarta: Sinar Grafika.

Undang-undang Républik Indonesia No 20 Tahun 2003 tentang Sistem 'Pendidikan Nasional. Jakarta: Departemen Pendidikan Nasional RI. 
Undang-undang Republik Indonesia. Nomor 23. Tahun 2002 Tentang Perlindungan Anak . Jakarta: Komisi Perlindungan Anak Indonesia.

Undang-undang Republik Indonesia Nomor 58 Tahun 2009 Tentang Standar Pendidikan Anak Usia Dini. Jakarta: Direktorat Jenderal Manajemen Pendidikan Dasar dan Menegah -Pendidikan Nașional.

\section{DATA:}

Departemen Pendidikan Nasional Republik Indonesia. Angka Kasar Pendidikan Anak Usia Dini (PAUD) Menurut Provinsi Tahun 2007/2008. (2008). Jakarta: Badan Penelitian dan Pengembangan Pusat Statistik Pendidikan-Departemen Péndidikan Nasional Republik Indonesia.

\section{INTERNET:}

www.antara.com.Senin 7 Nopember 2011. 